\begin{tabular}{|l|l|}
\hline & \\
\hline
\end{tabular}

SCRIPTURA

\title{
O discreto fim de nossos dias
}

\section{Juliana Maffeis ${ }^{1}$}

orcid.org/0000-0002-6962-4116 maffeisjuliana@gmail.com

Recebido em: 14 mai. 2019. Aceito em: 26 nov. 2019. Publicado em: 20 jul. 2020.

\section{(c) (1)}

Artigo está licenciado sob forma de uma licença Creative Commons Atribuição 4.0 Internacional.
I

Aurora morreu soterrada pelas coisas que guardava. Quando os vizinhos chamaram a polícia para dar conta do cheiro que vinha da casa foi preciso retirar tudo que cobria o chão. Os bombeiros estavam quase desistindo quando a cabeça de Aurora apontou no meio de uma coleção de bichos de pelúcia. Com o pescoço pendendo pro lado esquerdo, seu corpo foi puxado como acontece em um parto: Aurora estava nascendo para a morte.

Não se podia atravessar a fita amarela, não se podia modificar a cena do crime. A janela da casa de Aurora emoldurava um conjunto de travesseiros, enciclopédias, bonecas do tamanho de recém-nascidos, folhagens secas, panos que talvez fossem roupas e muitas panelas sem tampa. Quem olhava de fora pensava que a casa estava repleta de coisa boa e, ainda que não fossem tão boas assim, eram de graça.

Não demorou pra vizinhança tomar a casa. O interesse veio disfarçado de piedade com vela na mão, raminho de flor, meu sentimentos. Quando um mesmo objeto passou a ser cobiçado por mais de uma pessoa, acabou a diplomacia. Uma parte da vizinhança tentou ser discreta, mas logo chegou a gurizada com pedaço de pau e partiu pra cima das vidraças. Em seguida, chegou um carro com a caçamba aberta e passou a levar o que via de maior, como se volume fosse valor. A cachorrada latia inconformada.

Cada coisa tirada da casa parecia arrancada do corpo de Aurora. Uma sapateira comprada quando ela só usava um par de havaianas, um jogo de louças para jantar com a familia que não sabia seu endereço, uma caixa de som para apoiar os joelhos cansados de escalar suas próprias montanhas que cresciam diariamente.

Outra categoria que encantava Aurora era a dos achados de rua. Um pecado deixar esse móvel tomando chuva, que absurdo desperdiçar madeira boa assim, um dia posso precisar desse material para arrumar alguma coisa, dizia Aurora dando sobrevida às coisas.

Não conhecemos Aurora além da matéria, herança maldita. Quando o caminhão do lixo passava pela rua, a gurizada gritava pra levar embora a dona da casa. Aurora tinha vontade de furar os olhos risonhos dos guris com os espetos de ponta fina que seu pai usava para assar carne aos domingos.

Pontifícia Universidade Católica Do Rio Grande Do Sul (PUCRS), Porto Alegre,RS, Brasil 


\section{Ferro de passar}

Presente de casamento da madrinha de Aurora, o ferro servia para passar seu uniforme: um colete cinza, meio marrom, com a logo do Governo Federal em forma de cruz, nos dois lados na altura da barriga, acima dos bolsos. Tinha que cuidar para não grudar a base do ferro por cima do emblema do posto de saúde com o brasão da Prefeitura de Horizontinho, onde trabalhava há um perder de contas. Aurora vestia as roupas esperando que o movimento do corpo desmanchasse os vincos do tecido amassado.

Aurora podia estar dormindo enquanto esticava o tecido na tábua, andava tão cansada. $\mathrm{Na}$ cabeça, ela sentia o peso daquele ferro quente fritando as ideias. Os dedos longos dos colegas pareciam interessados em sua vida, apontando suas coisas. Questionavam tudo. Quando precisou autuar o dono de um restaurante, depois de encontrar uma colônia de baratas dentro do forno, percebeu o homem rindo. A vontade de Aurora era a de esquentar a panela com óleo que estava em cima do fogão e jogar por cima da cabeça do homem até ver os tufos de cabelo banhados no chão. Na porta da cozinha de Aurora não existia placa convidando ninguém para visitá-la.

\section{Liquidificador}

O barulho do liquidificador nunca mais interrompeu a sessão de desenhos das crianças. Não tem serventia! Aurora dizia sem saber se o motor ainda ligava. Pouco importava, realmente. Ninguém diria que dali tinham saido as mais elogiadas batidas de banana da região, com leite quente direto da teta da vaca e a banana fresquinha colhida do cacho no pátio. No cheiro de canela cabe a cena inteira: os três meninos no sofá de fralda de pano e bico na boca, como cabe a saudade dentro da fotografia pendurada na parede da sala, como cabe um mundo no mapa de uma cidade de poucas ruas.

As crianças riam da espuma do leite grudado no rosto da mãe, formando um bigodinho sobre os lábios bicudos que tentavam roubar beijo dos pequenos que, ao esconder uma bochecha com o ombro, acabavam revelando a outra. Não supor- tei ver o sofá vazio um único dia. Em cima da pia da cozinha sobrou o copo do liquidificador: uma forma colorida e aerada que o tempo encheu com $450 \mathrm{ml}$ de mofo em pleno estado de proliferação.

\section{Violão}

Batidas na porta: Aurora tinha pânico de receber visitas. Desde que seu filho mais velho saiu da cidade ela não esperava ninguém. O som das batidas insistentes sufocava Aurora. No pedaço de cama reservado para deitar, se encolheu usando um travesseiro para cobrir as orelhas. Não adiantou. Sei que tu tá ai dentro, velha ladrona!

Aurora tentava enfiar o resto do corpo além dos ombros, mas o espaço vazio era pouco. Os vizinhos diziam para a polícia invadir, que a viram entrar com o violão. Não havia ordem pra isso. Aurora devia abrir a porta, mas o medo de revelar o que tinha em casa era maior.

Escondendo a cabeça debaixo da cama, lembrou onde encontrou o violão. Era uma escadaria entre duas ruas. O braço estava encostado na parede e não havia ninguém por perto. Sentiu certo orgulho ao encontrar aquela peça em tão bom estado e chegou a suspeitar que pudesse estar afinado, mas não sabia comprovar.

O homem não invadiu a casa, a polícia tampouco. A vizinhança, apesar da vontade, manteve seus celulares prontos para capturar uma cena que não ocorreu. O tempo fechou e a chuva espantou a todos. Aurora seguia orando debaixo da cama até perceber que, na rua, havia apenas o barulho da chuva. Quando se levantou, buscou o violão com o olhar e encontrou o canto da parede descascada. Sentiu raiva. Fez o sinal da cruz e chamou o invasor de ladrão. Augusto ficou sem presente de Natal.

\section{Cama}

Mãe e filha acompanhavam a novela toda noite, sem perder um único capítulo e, no dia seguinte, durante a feitura do almoço comentavam sobre o que fizeram as personagens. Na maioria das vezes discutiam por não gostar das mesmas personagens. Aurora achava que a felicidade era coisa de novela. Era comum o pai chegar e desligar a televisão enquanto as duas assistiam à novela com 
olhos esbugalhados. Pra cama, as duas! Ele dizia apontando a porta do quarto. A cena interrompida desesperava Aurora, que deitava pensando o que estaria acontecendo com as personagens.

\section{Saco de lixo}

No dia em que Alexandre sumiu, Aurora gritou a noite inteira. Ninguém conseguiu dormir. O berro vinha da garganta e espancava o céu da boca. Não tinha como estancar o volume. Sem entender o que aconteceu, Augusto também chorava, chamando o irmão caçula pra jogar bola. As paredes da casa suavam de pânico. A polícia não encontrou pista sobre o paradeiro do menino. Aurora tinha certeza de que, de qualquer lugar, ele escutaria sua voz e voltaria, engatinhando pro seu colo.

Aurora caminhou Horizontinho inteira. Falou com cada morador. Ninguém tinha visto a criança. É mentira! Ela gritava na cara das pessoas. Em cada viela havia choro de criança. Em cada casa havia brinquedo de Alexandre. Em cada esquina a sombra do bebê se formava no chão. Não sobrou um canto da cidade onde Aurora não gritou. De volta pra casa, Aurora levou no colo - como quem carrega um bebê - um saco de lixo que tinha o tamanho exato de Alexandre. O lixo estava cheio de fralda suja. Aurora sentiu o cheiro do cocô do menino e dormiu a noite toda abraçada no saco plástico.

\section{Pano de prato}

Quando o circo chegava na cidade, Aurora tinha que bolar um plano para assistir ao espetáculo sem que seu pai suspeitasse. Bando de vadio! Ele chamava os artistas, batendo o punho cerrado na mesa. Aurora não entendia o tamanho da fúria e combinava com a mãe um plano pra conseguir sair de casa. Dessa vez, a mãe pediu para que Aurora levasse um pano de prato que havia bordado pra vizinha, que morava perto de onde o circo estava instalado. Aurora saiu faceira com o pano de prato dobradinho numa sacolinha de papel.

Um cordão de lâmpadas iluminou a praça sem energia elétrica. Aurora lançava o olhar em cima das meninas que dançavam e desejava ser uma delas. Andar por ai com roupas coloridas e de rosto pintado. Sorriso no rosto, unhas pintadas, postura impecável. No meio do espetáculo, o atirador de facas chamou Aurora para participar do jogo. Sem lembrar que toda cidade saberia que ela estava escondida no circo, Aurora desceu da arquibancada e se pôs de braços abertos em frente a um mural de madeira com um alvo desenhado. O homem cobriu os olhos com um lenço e atirou a primeira faca ao lado da barriga de Aurora, a segunda acertou o vazio entre as pernas e o terceiro sobre a cabeça, provocando aplausos do público. Aurora sentiu toda a energia do corpo expandir, abraçou e beijou a boca do atirador de facas.

\section{Panela}

Na casa de Josué não tinha uma panela. Tudo era muito diferente da casa dos pais de Aurora. Não que ela estivesse acostumada com luxo, nada disso. A mãe de Aurora colecionava panelas, tinha uma enorme coleção de formas e, só de chaleiras, tinha uma para cada boca do fogão. Ela estava acostumada com panelas e pratos e talheres e copos e xícaras e, por um momento, pensou que todas as casas do mundo tinham essas coisas. A casa de Josué não tinha panelas, mas tinha fogão.

Vamos comprar panelas, não te preocupa. Dizia Josué enquanto treinava a pontaria arremessando facas na parede de madeira. Aurora estava preocupada. Parecia que o estado de felicidade tinha acabado no momento em que não encontrou panelas na cozinha. Nunca imaginou que as panelas eram importantes para ela, mas não podia negar que lhe davam uma estranha sensação de segurança. Você vai cozinhar pra mim? Josué lambia os beiços. Aurora nem sabia cozinhar direito, mas queria panelas. Ela não pensava em cozinhar para alguém, mas para todos, para comer. Aurora juntou os trocados que a mãe havia lhe dado para lanchar durante a viagem e saiu para comprar uma panela.

Quando voltou de sacola na mão, encontrou as luzes apagadas. Aurora abriu a geladeira e tinha meia cebola, um pouco de margarina e uma garrafa de refrigerante sem gás. No armário, um pote com arroz e outro com café. Ouviu sua barriga roncar junto do ronco de Josué, que dormia 
no sofá com os braços abertos. Arroz é melhor que nada! Murmurou para si mesma, enquanto tentava estrear a panela. Riscou um fósforo e não conseguiu acender o fogão. Tentou outra vez: nenhum sinal de chama.

\section{Cadeira}

Sentado na cadeira da varanda, o pai de Aurora mascava um cigarro de palha e observava as meninas no caminho da escola. Quando alguém chegava perto, ele logo comentava que elas estavam cada vez mais safadas, usando roupas menores que o corpo. A cadeira estava sempre posicionada no mesmo ângulo e mantinha a mesma almofada magrinha com desenho de bunda. Era uma cadeira de madeira, robusta e confortável. Cada um tem que conhecer seu lugar. Aurora ouviu quando pequena no dia que sentou na cadeira para esperar o pai e saiu marcada de cinta.

\section{Livro}

Em Horizontinho, Aurora brincava com as crianças enquanto a mãe cozinhava. Não tinha homem para apontar dedo. As crianças não se preocupavam com surra. As mulheres podiam conversar sem medo. No fim do dia, a mãe de Aurora entrou em casa com uma caixa de livros. O governo vai abrir concurso neste fim de mundo. Aproveita, minha filha. Aurora enxergou o circo, as facas de Josué, a casa sem panelas, o pai na cadeira na varanda, a novela da televisão, as crianças dormindo no sofá e disse sim com a língua pesada de não.

\section{Lencinho}

Passada uma semana que Josué havia saido de casa, Augusto começou a perguntar pelo pai. No circo, ora, onde mais? Aurora respondia sem acreditar. Toda vez que alguém perguntava sobre Josué, Aurora sentia um calafrio e limpava o suor da testa com um lencinho bordado que havia sido de sua mãe. A comida estava acabando e não tinha mais um real dentro da latinha de Nescau que ele deixava para comprar as coisas de casa. A conta no armazém da esquina crescia e Aurora sabia que não dava para pedir favor nem ficar devendo para o povo da cidade grande.
A nova novela estava sendo gravada no centro de Constelação e Aurora ainda não tinha conseguido assistir nenhuma cena ao vivo, na praça da prefeitura. Naquele dia, Augusto foi passar a tarde na casa de um colega da escola e Aurora aproveitou para ver os atores famosos da televisão.

Não podia chegar muito perto, havia um cordão de isolamento e câmeras por todo lado. Aurora se aglomerou entre outras pessoas e, empurrando com o barrigão quem estava na frente, conseguiu um bom lugar debaixo do sol. Na segunda cena, era Josué - penteado e bem vestido - beijando a boca da protagonista da novela: entre orgulho, raiva e contração, Aurora não encontrou no bolso o lencinho da mãe.

II

Antes de a policia retornar, a vizinhança já havia tomado a casa de Aurora. Os vídeos que circularam no momento da confusão mostravam pessoas levando tudo o que encontravam. Havia quem entrou para buscar comida e quem levou a banheira cheia de lixo. Gente que pegou fogão e geladeira e brinquedo e sofá e toalha e panela e escada e janela e louça e tapete e tudo mais que cabia na mão, no carro e no carrinho de mão.

A esquerda de quem entrava na casa, via o corpo de Aurora, de bruços, e pisoteado e, à direita, um quarto fechado. A porta emperrada pelos objetos da parte de dentro do quarto fez com que os bombeiros precisassem remover a fechadura para o tombamento: um vômito de objetos tomou o chão da casa vazia quando a porta se abriu. Com a janela do quarto trancada e a entrada da casa interditada, a vizinhança não conseguia enxergar a operação. Os repórteres tentavam capturar algum depoimento, mas ninguém estava disposto a se comprometer.

Debaixo de uma mala cheia de sacolas, um pano se moveu. Aurora mantinha uma vasta coleção de almofadas que se rompia assim cruzava porta adentro. Os bombeiros passaram a procurar qualquer coisa diferente de flocos de espuma. O único quarto que continha coisas guardava tudo aos pedaços. Pelo de gato, resto de comida, louça quebrada, agulhas de crochê pela metade, páginas 
de livro, copo rachado, patins sem rodinha, bola furada, perna de boneca, pilha vazada, embalagem vazia e outros cacos disputados pela vizinhança. Da caverna de espuma surgiu um pé de criança: Alexandre, que estava desaparecido há nove anos. Com a pele do corpo marcada pelo peso do tempo, Alexandre foi resgatado enrolado em um cobertor com cheiro de mijo de gato. O menino que não sabia andar, também não sabia beber água, nem dizer obrigado. O policial levou Alexandre para viatura e os repórteres vieram atrás, com a boca cheia de perguntas impossiveis de reposta. No corredor do hospital, Alexandre tomou soro e foi encaminhado a um orfanato, onde dividiu o quarto com outras oito crianças nunca adotadas.

Juliana Maffeis

Programa de Pós-Graduação em Letras - Escrita Criativa da Universidade Pontificia Universidade Católica do Rio Grande do Sul. 